Egyptian Journal of Rabbit Science, 28 (1): 157 -171(2018)

\title{
EFFECT OF L-TYROSINE ADMINISTRATION ON MILK YIELD AND SOME BLOOD PARAMETERS IN NEW ZEALAND WHITE RABBITS DOES
}

\author{
M. Loutfi ${ }^{1}$; M. A. Ayoub ${ }^{2}$; H. A. Khalil ${ }^{2}$ and I. M. M. Assaf ${ }^{1}$ \\ 1-Department of Poultry Nutrition, Animal Production Research Institute, \\ Agricultural Research Centre, Dokki, Giza, Egypt. \\ 2-Department of Animal Production, Faculty of Agriculture, Suez Canal \\ University, Ismailia, Egypt.
}

Sixty five young New Zealand White (NZW) does were distributed randomly into five equal groups in a completely randomized design included four intervals doses of L-tyrosine administration according to the age at administration. The first group was served as a control (no treatment), while the second group (T1) was given a single dose of L-tyrosine $(100 \mathrm{mg} / \mathrm{kg} \mathrm{BW})$ at the second month of age, the third group (T2) was given two doses at 2 and at 4 months of age, the fourth group (T3) was given three doses at 2, 4 and at 6 months of age and the fifth group (T4) group was given four doses at 2, 4, 6, and at 8 months of age.

The results showed that L-tyrosine administration increased significantly $(P \leq 0.05)$ the weekly milk yield in the treated groups than in control group. $L$ tyrosine affected significantly $(P \leq 0.05)$ the concentration of estradiol hormone $\left(E_{2}\right)$ at 10 months of age and progesterone hormone $\left(P_{4}\right)$ at all ages. T1 group was higher than the other groups. Meanwhile L-tyrosine treatments did not affect on concentration of triiodothyronine $\left(T_{3}\right)$, total lipids, total protein, albumin, globulin and albumin/globulin $(A / G)$ ratio at 5 and 10 months of age .

In conclusion, effect of L-tyrosine administration $(100 \mathrm{mg} / \mathrm{kg} \mathrm{LBW})$ at two months of age increased total milk yield production and improved sexual hormones $P 4$ and E2 release significantly.

Key Words: Rabbits does, L-tyrosine, New Zealand, Milk yield, Blood parameters.

L-tyrosine treatment at specific stage of age led to significant improvements in reproductive and productive performance in rabbits (ElAmrawi, 2008). In treated Friesian dairy cows with L-tyrosine during early postpartum period daily milk production increased $(\mathrm{P} \leq 0.05)$ during the $1^{\text {st }}$ four months of lactation (Gabr, 2012). Also in ewes, Yassin et al. (2011) showed 
significant increase in milk production as a result of L-tyrosine oral administration. In addition, L-tyrosine treatment showed a positive reflection on goats milk yield of fat, protein and lactose and showed higher levels when compared to the control group (Abu El-Ella et al, 2014).

In immature does of NZW rabbit, Omara et al. (2005) found that Ltyrosine administration as one oral dose (100 $\mathrm{mg} / \mathrm{kg} \mathrm{LBW})$ at 49 days of age or two oral doses at 49 and 79 days of age resulted in significant increase in serum concentration of $\mathrm{T}_{3}, \mathrm{~T}_{4}, \mathrm{E}_{2}$ and progesterone $\left(\mathrm{P}_{4}\right)$ hormones. In ewe lambs, $\mathrm{L}$ tyrosine increased significantly $(\mathrm{P} \leq 0.05)$ progesterone hormone $\left(\mathrm{P}_{4}\right)$ levels when compared to control (El-Battawy, 2006). In addition to El-Amrawi et al (1991) found that the plasma progesterone levels increased at estrus after treatment of anestrus buffaloes with L-tyrosine. On the other hand, Abu El-Ella et al. (2011) found $\mathrm{P}_{4}$ concentration was similar in goat does for all groups without significant differences when they were supplemented with L-tyrosine at mating (onset of estrus). In goats, L-tyrosine supplementation led to increase concentrations of thyroid hormones and prolactin levels (Ibrahim, 2010).

Plasma total protein and globulin concentrations were higher $(\mathrm{P} \leq 0.05)$ in treated calves than in control group in Friesian calves received L-tyrosine (Abu EI-Hamd (2012). Also in heifers, Afet (2014) reported that concentrations of total blood plasma proteins, globulin, glucose and albumin/globulin ratio increased after L-tyrosine supplementation. In goats, L-tyrosine administration significantly increased blood albumin and glucose concentration as compared to the control. Meanwhile, blood globulin decreased significantly due to L-tyrosine administration (Abu El-Ella et al., 2014).

Therefore, the aim of the present work was to study the effect of Ltyrosine administration at different ages on some blood parameters, sexual hormones and milk yield in New Zealand White (NZW) rabbits does.

\section{MATERIALS AND METHODS}

The present study was carried out at a Private Rabbit Farm in Husseiniya, Sharkia Governorate, Egypt, during the period January, 2016 to February, 2017. Sixty five immature NZW does were distributed randomly into five equal groups in a completely random design included four intervals doses of L-tyrosine (L-tyrosine Pure Extra $99 \%{ }^{\circledR}$, Alpha Chemika, India) according to the age at administration. The first group was served as a control 
(no treatment), while the second group (T1) was given a single dose of Ltyrosine $(100 \mathrm{mg} / \mathrm{kg} \mathrm{BW})$ at the second month of age, the third group (T2) was given two doses at 2 and at 4 months of age, the fourth group (T3) was given three doses at 2, 4 and at 6 months of age and the fifth group (T4) was given four doses at 2, 4, 6, and at 8 months of age. At the beginning of the experiment, age of animals averaged two months and their weight was similar $(1544.22 \pm 10.78 \mathrm{~g})$. All rabbits were individually housed in galvanized wired cages, where feed and water were provided ad libitum. Rabbits were fed on basal pellet ration contained yellow corn, soybean meal, clover hay, minerals and vitamins premix. The chemical composition of the commercial pelleted diet was as the following: crude protein $17.03 \%$, ether extract $2.40 \%$, crude fiber $12.65 \%$ and digestible energy $2675.00 \mathrm{Kcal} / \mathrm{Kg}$. according to NRC (1977). Rabbits were kept continuously under the same managerial and environmental conditions during the whole experimental period. Rabbits were healthy and free of any external parasites or skin diseases.

Blood samples $(3 \mathrm{ml})$ were taken twice from four does in each group. The first sample was taken pre-mating at 5 months of age and the second sample was taken at 10 months of age in the seventh day post parturition before mating. The blood sample was collected from the central ear vein which was cleaned with absolute alcohol. Xylol was applied on ear to increase blood flow (Hoppe et al., 1969). Blood samples were collected by a syringe and centrifuged at 3,000 rpm for $15 \mathrm{~min}$. The serum was removed and stored frozen at $-20 \mathrm{C}^{\mathrm{o}}$ until analysis.

Milk yield for each doe was recorded for one day/week at 8:00 am as the difference in the weight of pups before and after suckling. The pups were separated before suckling for 14 hour at the $1^{\text {st }}, 2^{\text {nd }}, 3^{\text {rd }}, 4^{\text {th }}$ week of lactation period.

Serum concentration of estradiol $\left(\mathrm{E}_{2}\right)$, progesterone $\left(\mathrm{P}_{4}\right)$ and triiodothyronine $\left(\mathrm{T}_{3}\right)$ were determined by Electro-chemiluminescence immunoassay (ECLIA) technology using Siemens ADVIA Centaur ${ }^{\circledR}$ Immunoassay System (Siemens Healthcare $\mathrm{GmbH}$, Germany). The intra-assay $\mathrm{CV}$ was $8 \%$, inter-assay CV was $6.3 \%$ for estradiol. The intra-assay and interassay $\mathrm{CV}$ for $\mathrm{T} 3$ values were lower than $6.2 \%$ and $7.1 \%$, respectively. The intra-assay and inter assay C.V. were less than $10 \%$ for the $\mathrm{P} 4$.

Serum total protein, total lipids and albumin were determined by colorimetric assay using auto analyzer Dimension ${ }^{\circledR}$ RxL Max ${ }^{\circledR}$ Integrated 
chemistry system (Siemens Healthcare GmbH, Germany). Intra- and inter assay precision were in all instances below 3 and $4 \mathrm{CV} \%$, respectively. Globulin was calculated by subtracting between serum total protein and albumin content. Albumin/globulin ratio was calculated.

Data were statistically analyzed as completely randomized design according to Snedecor and Cochran (1982) using analysis of variance procedure described by SPSS (2011). The mathematical model was as follows:

$$
\mathrm{Y}_{\mathrm{ij}}=\mu+\mathrm{A}_{\mathrm{i}}+\mathrm{E}_{\mathrm{ij}}
$$

Where, $Y_{i j}=$ An observation, $\mu=$ The overall mean, $A_{i}=$ Effect of L-tyrosine treatments ( $\mathrm{i}=1$ to 5 ), and $\mathrm{E}_{\mathrm{ij}}=$ Random error.

Significant differences among treatments were tested by Duncan's Multiple Range Test (Duncan, 1955).

\section{RESULTS AND DISCUSSION}

\section{Total weekly milk yield}

The averages weekly of total milk yield ( $\mathrm{g} / \mathrm{day} / \mathrm{doe})$ during the four weeks from birth to weaning age was affected by L-tyrosine treatments are presented in Table 1.

The treatment with L-tyrosine administration significantly $(\mathrm{P} \leq 0.05)$ increased average milk yield during the second and the third weeks after parturition and also during the total period of lactation in all treated groups compared to control group. On the other hand, milk yield was increased in the treated does with L-tyrosine during the first and the fourth weeks without significant differences compared to control group. Figure (1) showed the increase in total weekly milk yield in all treated does with L-tyrosine was higher $23.94 \%$ to $34.9 \%$ over the control group.

Milk yield increase is mostly referred to the increase in blood supply (Mepham, 1982) and the energy intake of mammary gland cells (Wurtman, 1982), in addition to its effect on increasing growth hormone via its effect on brain catecholamines (Martin, 1980). Peel et al. (1981) found significant increase in milk yield as a result of L-tyrosine administration and may be due 
Table1. Effect of L-tyrosine treatments on the average weekly milk yield at first, second, third, fourth week of suckling and total milk yield ( $\mathrm{g}$ /day/doe, Means \pm S.E)

\begin{tabular}{|c||c|c|c|c|c||}
\hline Treatments & $\begin{array}{c}\text { First } \\
\text { week }\end{array}$ & $\begin{array}{c}\text { Second } \\
\text { week }\end{array}$ & $\begin{array}{c}\text { Third } \\
\text { week }\end{array}$ & $\begin{array}{c}\text { Fourth } \\
\text { week }\end{array}$ & $\begin{array}{c}\text { Total } \\
\text { milk yield }\end{array}$ \\
\hline \hline \multirow{2}{*}{ Control } & 106.50 & 137.50 & 167.75 & 73.50 & 485.25 \\
\pm 3.88 & $\pm 13.17^{\mathrm{b}}$ & $\pm 26.64^{\mathrm{b}}$ & \pm 21.27 & $\pm 48.07^{\mathrm{b}}$ \\
\hline \multirow{2}{*}{ T1 } & 136.00 & 188.33 & 220.17 & 108.67 & 653.17 \\
& \pm 12.43 & $\pm 6.64^{\mathrm{a}}$ & $\pm 14.56^{\mathrm{a}}$ & \pm 17.89 & $\pm 29.48^{\mathrm{a}}$ \\
\hline \multirow{2}{*}{ T2 } & 135.40 & 179.00 & 204.20 & 82.80 & 601.40 \\
& \pm 8.99 & $\pm 12.12^{\mathrm{a}}$ & $\pm 13.07^{\mathrm{a}}$ & \pm 15.11 & $\pm 18.99^{\mathrm{a}}$ \\
\hline \multirow{2}{*}{ T3 } & 121.83 & 202.17 & 207.83 & 97.67 & 629.50 \\
& \pm 16.59 & $\pm 15.32^{\mathrm{a}}$ & $\pm 20.44^{\mathrm{a}}$ & \pm 20.40 & $\pm 35.61^{\mathrm{a}}$ \\
\hline \multirow{2}{*}{ T4 } & 145.33 & 210.67 & 203.67 & 89.33 & 649.00 \\
& \pm 8.41 & $\pm 7.31^{\mathrm{a}}$ & $\pm 1.76^{\mathrm{a}}$ & \pm 9.06 & $\pm 8.33^{\mathrm{a}}$ \\
\hline \hline \multirow{2}{*}{ Significance } & \multirow{2}{*}{$\mathbf{N S}$} & $* *$ & $*$ & NS & $*$ \\
\hline \hline
\end{tabular}

a,b Means with different superscripts in the same column are significantly different with respect to their P-values. NS $=$ Not significant $*=$ Significant $\mathrm{P} \leq 0.05 * *=$ Significant $\mathrm{P} \leq 0.01$.

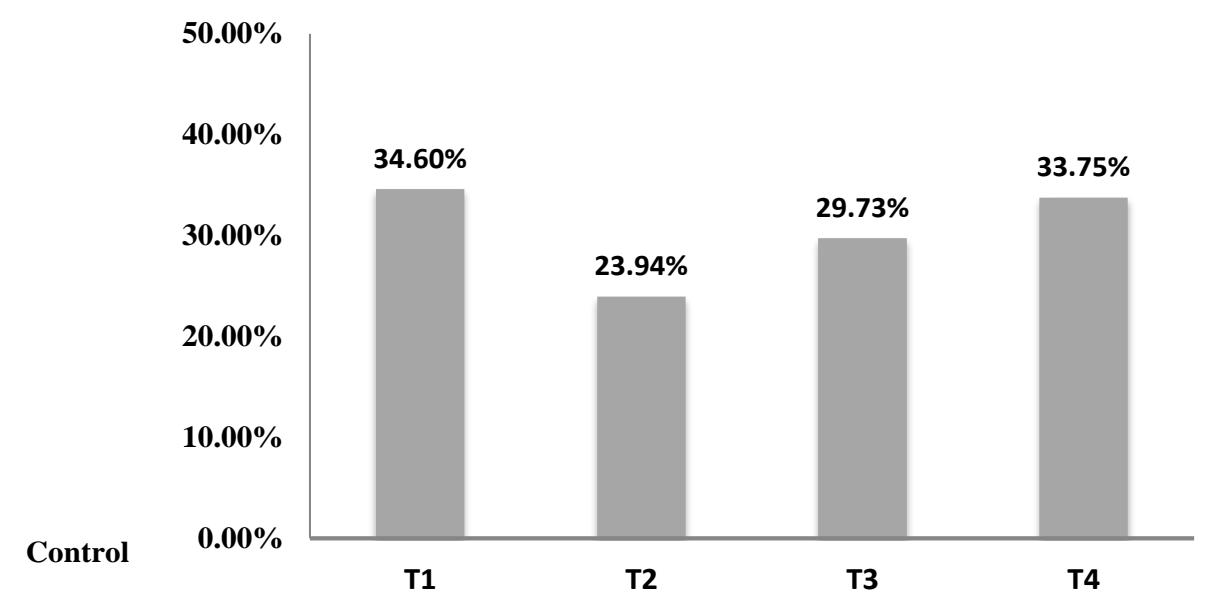

Figure (1). Percent change in the average weekly milk yield as affected by L-tyrosine treatments in NZW does over the untreated does. 
The results are in agreement with Yassin et al. (2011) who showed significant increase in milk production as a result of L-tyrosine oral administration in ewes. In addition, Gabr (2012) found that L-tyrosine treatment improved significantly daily milk production and milk composition in Friesian dairy cows.

\section{Blood parameters}

\subsection{Hormonal profile}

\subsubsection{Estradiol hormone (E2)}

The effects of using L-tyrosine administration on serum estradiol $\left(\mathrm{E}_{2}\right)$ levels of does at different ages are presented in Table 2. At 5 month of age, serum concentration of $\mathrm{E}_{2}$ increased insignificantly in all treated groups compared with control group. However, the results revealed that significant differences were detected due to treatments in serum concentration of $E_{2}$ at 10 months of age. The females in $\mathrm{T} 1$ showed significant increase $(\mathrm{P} \leq 0.05)$ in serum concentration of $\mathrm{E}_{2}$ compared with control and treated groups.

L-tyrosine supplementation during and post sexual puberty stage led to a reduction in sexual activity and inhibited ovarian activity compared to T1 Group which received a single dose of L-tyrosine at two months of age as shown in cows by Gabr (2012). The same author found that L-tyrosine inhibited follicular growth in the ovary and led to a decrease in average number of estrus cases and ovulatory cycles per cow during the ovulatory cycles. Also Wetzel (1985), Hammerl (1986) and Munsterer (1987) found a low number of estrus per cow which was associated with the exogenous Ltyrosine treatment. In NZW rabbits, Omara et al. (2005) found that administration of an oral dose $(100 \mathrm{mg} / \mathrm{kg} \mathrm{LBW})$ of L-tyrosine resulted in an earlier significant increase $(\mathrm{P} \leq 0.05)$ in serum $\mathrm{E}_{2}$ hormone concentration as compared to control while administration of second dose of L-tyrosine at the mid of the third months of age resulted in further significant increase in $E_{2}$ concentration.

\subsubsection{Progesterone hormone $\left(\mathrm{P}_{4}\right)$}

The effects of using L-tyrosine on serum progesterone $\left(\mathrm{P}_{4}\right)$ levels at different ages are presented in Table 2. Significant differences were detected due to treatments in serum concentration of $\mathrm{P}_{4}$ at 5 and significant differences $(\mathrm{P} \leq 0.01)$ were detected at 10 months of age. Serum concentration of $\mathrm{P}_{4}$ increased significantly in $\mathrm{T} 1$ as compared with control and treated groups. 
This increment in $\mathrm{P}_{4}$ hormone may be due to the stimulatory effect of Ltyrosine on $\mathrm{GnRH}$ of doe rabbits. L-tyrosine may involve stimulation of $\mathrm{GnRH}$ release because availability of L-tyrosine influences synthesis of norepinephrine (Wurtman et al., 1981 and Acworth et al., 1988), a neurotransmitter that stimulates hypothalamic GnRH release, pulsatile and preovulatory release of LH hormone from pituitary gland (Ramirez et al., 1984 and Terasawa et al., 1988). The catecholamines may mediate effect of other neurotransmitter and gonadal steroids on release of GnRH (Yen and Vale, 1990). On the other hand, decreasing in level of $\mathrm{P}_{4}$ hormone in the other treated groups (T2, T3 and T4) may be returned to L-tyrosine treatments post sexual puberty which led to reduce sexual activity and inhibited ovarian activity compared to female in T1 as well as reported by Gabr (2012). Also, Abu ElElla et al. (2011) found that concentration of $\mathrm{P}_{4}$ hormone was less than 0.5 $\mathrm{ng} / \mathrm{ml}$ in treated goat females when they supplemented with L-tyrosine at mating (onset of estrus).

\subsubsection{Triiodothyronine hormone $\left(T_{3}\right)$}

The effects of using L-tyrosine on serum T3 levels at different ages are presented in Table 3. The results revealed that insignificant differences due to treatments in serum concentration of $\mathrm{T} 3$ in both testing ages. Serum concentration of $\mathrm{T} 3$ decreased insignificantly in $\mathrm{T} 4$ compared with control and treated groups at 5 and 10 months of age.

The current findings disagreed with results of Omara et al., (2005) who found that an oral supplementation of L- Tyrosine in NZW rabbits increased serum $T_{3}$ and $T_{4}$ hormones concentrations significantly $(P \leq 0.05)$. Also in goats reported that L-tyrosine supplementation led to an increase in $\mathrm{T}_{3}$ and prolactin hormones concentration (Ibrahim, 2010). On the other hand, Palinkas et al., (2007) reported that administration of L-tyrosine led to significant reduction in serum thyroid stimulating hormone (TSH).

\subsection{Blood biochemical components profile}

The effect of L-tyrosine treatments on all blood biochemical profile (total Protein, total Lipids, albumin, globulin and albumin/ globulin ratio were not significant detected among the treated groups and control group at 5 and 10 months of age as presented data in Table 4. 
LOUTFI et al. 
These results were in agreement with Abu El-Ella et al. (2014) who found that L-tyrosine did not change concentration of total protein in treated goats does. Krajnıèáková et al. (2003) recorded a statistically significant decrease ( $\mathrm{P} \leq$ 0.01 ) in total lipid level on day 7 post parturition in goats. Abu EI-Hamd (2012) and Afet (2014) reported that the L-tyrosine supplementation did not affect significantly albumin concentration in blood in heifers and the valves of albumin. Also in goats, L-tyrosine administration significantly increased blood albumin concentration compared to the control does (Abu El-Ella et al., 2014). These result values pointed out to normal performance of the rabbits and were within the normal range of the values reported by Habeeb et al. (1994), Marai et al. (1999)., Soliman et al. (2000) and Salem et al. (2003). These values indicated that the animals were generally in a good nutritional status and their livers were in normal physiological condition. Normal globulin values indicated good immunity status of animals. Also it is worthy to note that the values of A/G ratio were higher than 1.0 which indicates that animals did not suffer from any health problem that might affect the performance of experimental animals as reported by EL-Sayed et al. (2002).

Conclusively, effect of L-tyrosine administration (100 mg/kg LBW) at two months of age increased total milk yield production and improved sexual hormones $\mathrm{P}_{4}$ and $\mathrm{E}_{2}$ release significantly.

\section{REFERENCES}

Abu El-Ella, A. A., El-Gohary, E. S., Abdel-Khalek, T. M. M. and AbdelSamee, A. M. (2011). Productive and reproductive performance of goats as affected by L-tyrosine supplement: Sexual activity and reproductive performance. Egyptian Journal of Sheep \& Goat Sciences, Vol. 6 (2),37 46.

Abu El-Ella, A. A., El-Gohary, E. S., Abdel-Khalek, T. M. M. and AbdelSamee, A. M. (2014). Productive and reproductive performance of goats as affected by L-tyrosine administration. Egyptian Journal of Sheep \& Goat Sciences, Vol. 9 (1), P: 43- 57, 2014.

Abu El-Hamd, M. A., Sayah, M. S., Shamiah, Sh. M. and Gabr, Sh. A. (2012). Effect of L-tyrosine on growth performance and some blood constituents of suckling Friesian calves during winter and summer seasons. Egyptian J. Anim. Prod., 49 Suppl. Issue, Nov. (2012):57-63. 
Acworth, I. M., During, M. J. and Wurtman, R. J. (1988). Tyrosine: Effects on catecholamine release. Brain Res. Bull., 21: 473-477.

Afet, M. G. (2014). Effect of L-tyrosine supplementation on productive and reproductive performance in Friesian heifers. M. Sc. Thesis, Fac. Agric. kafrelsheikh University. Egypt.

Duncan, D. B. (1955). Multiple range and multiple F-test. Biometrics, 11: 1-42.

El-Amrawi, G. A. (2008). Effect of Theriogon in concentration of testosterone in buffalo-bulls. $16^{\text {th }}$ International Congress on Animal Reproduction (ICAR) 12-16 Juli Budapest. Hungura.

El-Amrawi, G. A., Zakaria, A. D. and Nasr, M. T. (1991). L-tyrosine and ovarian activity in Egyptian buffaloes. Assiut Vet. Med. J. 25 (50): 211-216.

El-Battawy, K. A. (2006). Reproductive and endocrine characteristics of delayed pubertal ewe-lambs after melatonin and L-tyrosine administration. Reprod. Domestic Anim., 41(1):1-4.

El-Sayed, H. M., El-Ashry, M. A., Metwelly, H. M., Fadel, M. and Khorshed, M. M. (2002). Effect of chemical and biological treatments of some cropresidues on their nutritive value: 3- Digestion coefficient, rumen and blood serum parameters of goats. J. Nutrition and Feeds, 5(1): 55-69.

Gabr, Sh. A. (2012). Reproductive performance and milk yield of Friesian dairy cows affected by L-tyrosine treatment during early postpartum period. Life Sci J., 2012, 9 (4):4486-4489]. (ISSN: 1097 8135).

Habeeb, A. A. M., Marai, I. F. M., El-Sayiad, G. A. and Nessen, M. Z. (1994). Effects of internal and external cooling techniques on growth and physiological functions of New-Zealand White and California rabbits maintained under hot summer conditions of Egypt. $1^{\text {st }}$ International Conference on Rabbit Production in Hot Climates, Cairo, Options Mediterranean's, 8 (Supplement), 626.

Hammerl, J., (1986). Der Einfluß der Aminosaure L-Tyrosin, als ein Katecholamin-Vorlaufer, auf die Reproduktion bei Ku“ hen. In: Proc. 14th World Cong. on Diseases of Cattle. Vol 2. p 911. Dublin, U.K.

Hoppe, P. C., Laird, C. W. and Fox, R. R. (1969). A simple technique for bleeding the rabbit ear vein. Lab. Anim. Care., 19: 524-525.

Ibrahim, M. Y. M. (2010). Some studies on improving productive and reproductive performance of local sheep. Ph.D. Fac. Agric Minia Univ., Egypt. 
Krajnıèáková, M., Kováè, G., Kostecký, M., Valocký, I., Maraèek, I., Šutıaková, I. and Lenhardt, U. (2003). Selected clinico-biochemical parameters in the puerperal period of Goats. Bull. Vet. Inst. Pulawy, 47:177182.

Marai, I. F. M., Ayyat, M. S., Gabr, H. A. and Abd El-Monem, U. M. (1999). Growth performance, some blood metabolites and carcass traits of NZW male rabbits as affected by heat stress and its alleviation under Egyptian conditions. $2^{\text {nd }}$ International Conference on Rabbit Prod. In Hot Climate, Vol. 41:35.

Marcek, J. M., Seaman, W. J. and Nappier, J. L (1989). Effect of repeated high dose administration of recombinant bovine somatotropin in lactating dairy cows. Vet. Hum. Toxicol., 72:2955-2958.

Martin, J. B. (1980). Functions of central nervous system neurotransmitters in regulation of growth hormone secretion. Fed. Proc. 39:2902.

Mepham, T. B. (1982). Amino acid utilization by lactating mammary gland. $J$. Dairy Sci. , 65:287.

Munsterer, P. (1987). Zur Anwendung der aminosure Ltyrosin in der sterilitats behandlung des Milchrindes. Diss.Med Vet., Munchen.

NRC (1977). Nutrient Requirements of Rabbits. $2^{\text {nd }} \quad$ Ed. National Academy of Science, Washington, DC. USA.

Omara, M. E., Mahmoud, S., A. and Saad, M. F. (2005). Effect of L-tyrosine on productive and reproductive performance of female New Zealand rabbits. Vet. Med. J. ,Giza, Vol. 53, No.2. 381-394.

Palinkas, L. A., Reedy, K. R., Smith, M., Anghel, M., Steel, G. D., Reeves, D., Shurtleff, D., Case, H. S., Do, N. V. and Reed, H. L. (2007). Psychoneuroendocrine effects of combined thyroxine and triiodothyronine versus tyrosine during prolonged Antarctic residence. International Journal of Circumpolar Health, 66(5):401-417.

Peel, C. J., Bauman, D. E., Gorewit, R. C. and Sniffen, C. J. (1981). Effect of exogenous growth hormone on lactational performance in yielding dairy cows. J. Nutr. 111:1662

Ramirez, V. D., Feder, H. H., and Sawyer, C. H., (1984). The role of brain catecholamines in the regulation of LH secretion: A critical inquiry. In: L. Martini and W. F. Ganong (Ed.) Frontiers in Neuroendocrinology (Vol. 8). p 27. Raven Press, New York, USA. 
Salem, F. A., El-Mahdy, M. R. and El-Medany, N. M. (2003). Influence of ascorbic acid supplementation on productive performance, digestion coefficients, some blood constituents and carcass traits of growing New Zealand White rabbits. Egyptian Journal Rabbit Science, 13: 37.

Snedecor, G. W. and Cochran, W. G. (1980). Statistical Methods., 7th Ed. Allied Pacific, Bomobay.

Soliman, A. Z. M., El-Kady, R. I., El-Shahat, A. A. and Sedik, M. Z. (2000). Effect of some commercial growth promoters on the growth performance and caecum microbiology of growing New Zealand White rabbits. Egyptian Journal of Rabbit Science, 10 (2): 239.

SPSS (2011). Statistical Package For The Social Sciences, Release: 20, SPSS INC, Chicago, USA.

Terasawa, E., Krock, C., Hei, D. L., Gearing, M., Schultz, N. J. and Davis, G. A. (1988). Norepinephrine is a possible neurotranasmitter stimulating pulsatile release of luteinizing hormone releasing hormone in the rhesus monkey. Endocrinology, 123:1808-1816.

Wetzel, G., (1985). Der Einfluß der Aminosaure L-Tyrosin auf das Fruchtbarkeitsgeschehen beim Rind. Vet. Dissertation. Univ. of Munich, Germany.

Wurtman, R. J. (1982). Nutrients that modifybrain function. Sci. Am., 246:50-59.

Yassin, M., El-Barody, M. A., Gabr, M. G. K., Safaa, N. A., Elmoty, A. K. I. A., El-Hakeam, A. A. A. (2011). Post-lambing productive and reproductive performance of Ossimi ewes as affected by Theriogon oral administration during three sequence breeding seasons. Egyptian Journal of Nutrition and Feeds,. 14(3):359-365.

Yen, S. S. C., and Vale, W. V. (1990). Neuroendocrine regulation of reproduction. In: Proc. Symp. Neuroendocrine Regulation of Reproduction, November 5-9, 1989, Napa, CA. 


\title{
تأثير الحقن بالتيروسين على محصول اللبن وبعض مقاييس الام لإناث أرانب النيوزيلندى الابيض النيض
}

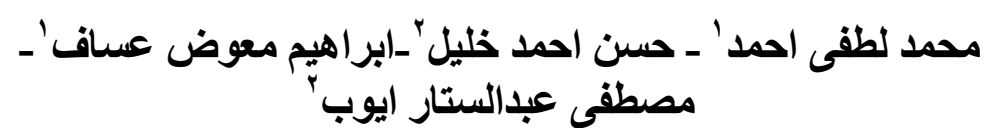 \\ ا ـ قسم تغذية الدو اجن - معهد بحوث الانتاج الحيو انى ـ مركز البحوث الزئر اعيةــ

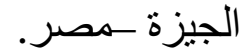 \\ كـ قسم الانتاج الحيوانى و الثروة السمكية ـ كلية الزر اعة ـ جامعة قناة السويس-

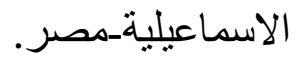

أجريت هذة التجربة بهف دراسة تأثير الحمض الأمينى التيروسين على أنتاج اللبن

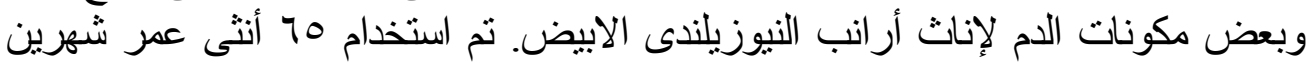

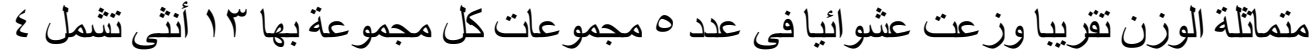
فترات زمنية مختلفة لإضافة التيروسين كانت المجموعة الأولى التهي الكنترول (بدون معاملة)

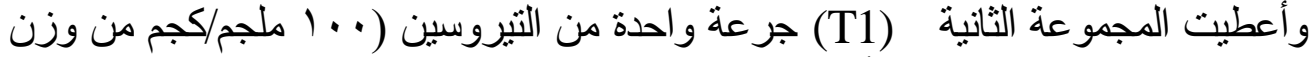

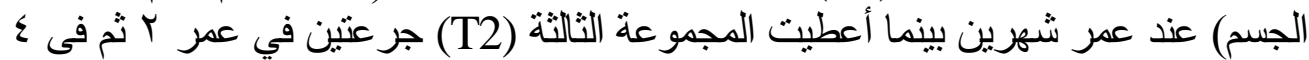

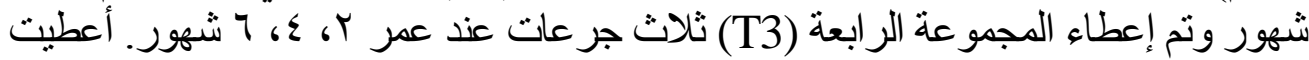

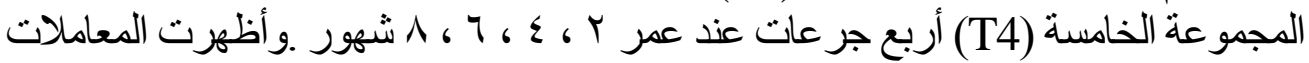

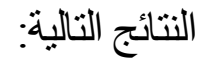

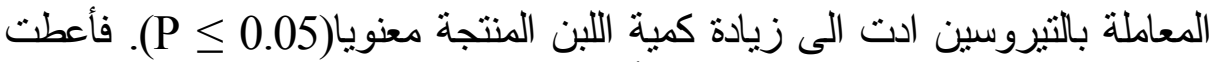

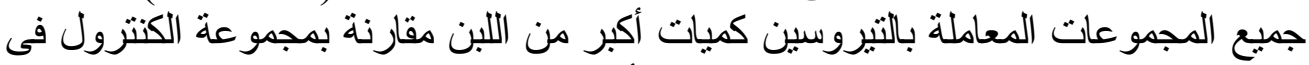

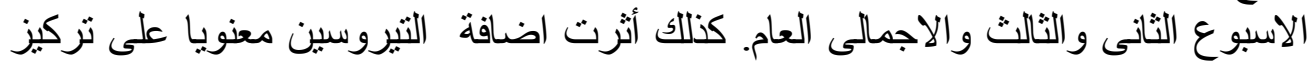

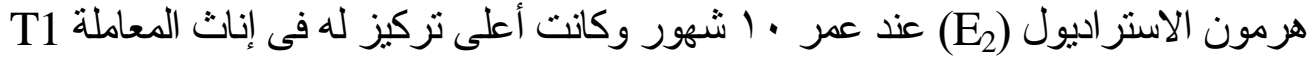

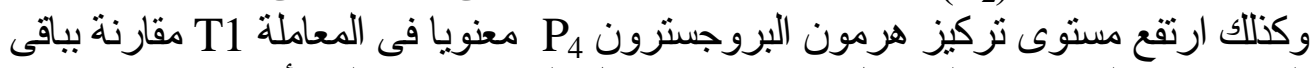

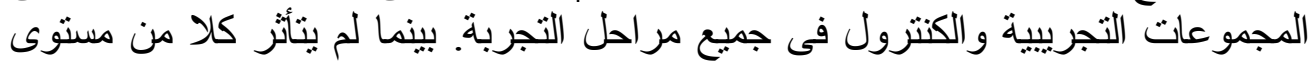

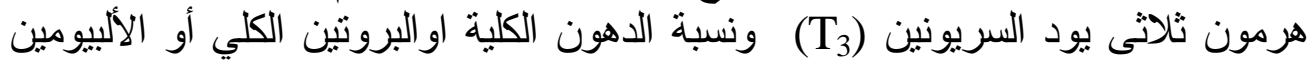

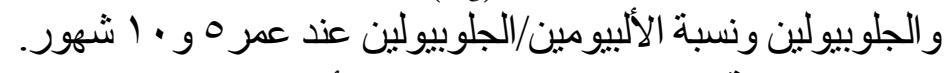

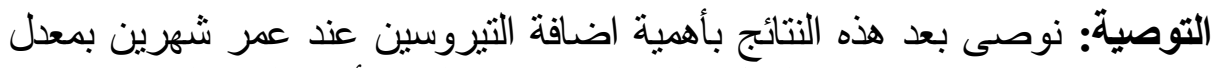

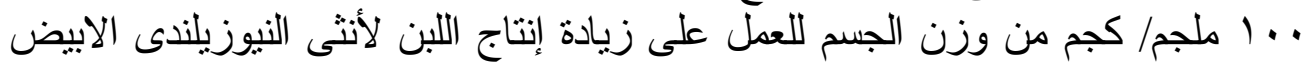

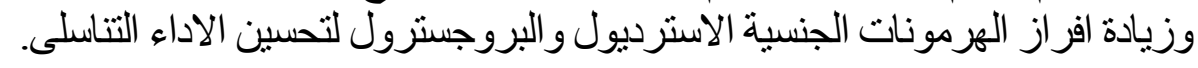

